\title{
REFLECTIONS ON POETIC MODELS OF ORGANIZATIONAL CHANGE: AN ANALYSIS OF VAN DE VAN'S TYPOLOGY IN LITERARY, LINGUISTIC, PSYCHOLOGICAL AND MANAGERIAL PERSPECTIVE
}

\author{
Ayesha Ali
}

Doctoral Scholar, University of the Punjab, Pakistan, and Deputy Director, Higher Education Commission, Punjab, Pakistan. Email:22ayesha11@gmail.com

Article History: Received on $31^{\text {st }}$ March 2021, Revised on $15^{\text {th }}$ May 2021, Published on $30^{\text {th }}$ May 2021

\section{Abstract}

Purpose of the study: This article is an attempt to reflect on and locate similarities and develop synchronicity between the fields of organizational change, management, psychology, language, and literature. The reflective learning takes place through reflective practice conducted on literature and organizations to generate new knowledge and ways to comprehend and deal with issues. Thus, the rationale for uniting contributions of management and English can be logically found in the processes of nature and human life.

Methodology: This article is based on rational reasoning and critical analytic comparisons that aptly explain that the four models of organizational change are not new rather proclaimed in poetic expressions several years or a century ago.

Main Findings: The organizational models of change are reflected in literature which has explained how Management by Objectives, organization as systems, mechanistic and organic organizations work and how they can be maneuvered towards increasing organizational productivity and performance.

Applications of this study: This inquiry shall help further examination of various fields to develop new management concepts through bargain and borrowing.

Novelty/Originality of this study: This article, through reasoning and analysis, has developed four life like models i.e., Miltonic, Frostian, Shelleyan, and Eliotic models of organizational change which seem to be preceding the current existing theories on teleological, life cycle, evolutionary and dialectical models of organizational change.

Keywords: Poetic Models of Organizational Change, Van de Van's Typology, Miltonic Model, Teleological Model, Shelleyan Model, Life Cycle Model, Frostian Model, Dialectical Model, Eliotic Model, Evolutionary Model.

\section{INTRODUCTION}

The article aims to draw the roots of the organizational model of change in the classics offered in literature which is a reflection of society and human processes. This article is an endeavor to trace similarities and build up synchronicity, between the field of organizational change, management, psychology, language, and literature. The rationale is that the reflections on literature and organizations generate new knowledge and ways to comprehend and deal with organizational issues. In this backdrop, literary passages found in the works of Milton, Frost, Shelley, and Eliot provide sufficient knowledge to understand types and models of organizational changes as propounded by Van de Van (1995). The objective and raison d'être of the study is to combine contributions of management and English that can be plausibly found in the processes of the natural realm and human life. The objective is to find similarities and sufficient knowledge in literature to make the Van de Van's typology of organizational change comprehensible and pave way for further development through existing evidences of literature, besides, the common modes of research and development being practiced in the specific field which either starts from scratch or assumes more time to develop when based on mere observation.

Methodologically, this article is founded on cogent reasoning, analysis and critical comparisons that aptly elucidate that the four models of organizational change are not up-to-the-minute rather asserted in poetic expressions several years or a century ago - as explains the research problem. The research problem relates to the fact that models of organizational change can be better understood and developed if comprehended and analyzed in the light of life reflecting literature. This will ease the future developments and research by taking advantage of existing and time-tested knowledge rather than re-inventing the wheel in other disciplines.

The study is conducted to find the answer to the research question that whether the literature, which claims to be a reflection of real-life phenomena, offers sufficient knowledge to help us understand the organizational models of change as presented in Van de Van's typology. This is reflected by (Boonstra, 2000) that changes in surroundings cause changes in organizations. Here, the changes in surroundings are also reflected in literature. This quest shall be of assistance for advanced inspection of diverse fields to extend new management concepts through bargain and borrowing. Also, such analysis will provide adequate knowledge to enhance understanding which will further develop models of organizational change. 
The analysis helps to develop organizational theories of change including goal setting, strategic choice, functionalism, adaptive learning, and decision-making theories by seeking explanations and reflections in the literature found in works of Milton, Frost, Shelley, and Eliot. However, the focus shall be kept on Van de Van's typology of organizational change. The analysis will revolve around the fact that which elements, processes, attributes, and factors are reflected in literature and how they are reflected in typology, that contribute to the development and explanations of organizational models of change. On this ground, the models are termed Miltonic, Frostian, Shelleyan, and Eliotic models of change.

\section{Research Question}

Q. How can literature, a reflection of life in society, provide beneficial models of change in organizational life?

\section{LITERATURE REVIEW}

Pilny et al. (2016) explain that organizations are defined by various interaction processes aimed at survival, growth, success, and failure. This includes resource allocation (Bakker, 2018), flexibility and connectivity in working to achieve efficiency (Kotera \& Vione, 2020), and regulatory frameworks and interventions which determine organizational change (Cortet, 2016). Also, the researchers have investigated communication about change in organizations (Leonardi, 2017), and such communications are conveyed by effective leadership (Schaufeli, 2015) and positive managerial behaviors towards organizational change (Dery, 2017).

The phenomenon of change has become the constant state of the present-day organization (Kotter, 1995). Organizational change can be empirically observed in an organizational unit through variations in form, quality, or condition in due course of time (Van de Ven \& Poole, 1995), which are introduced deliberately by new means of reflecting, acting, and functioning (Schalk et al., 1998).

There are changes of the first order usually evolutionary and incremental changes. These are little changes altering specific minute aspects that look for development in the current situation, however, these keep up the common working structure (Greiner, 1972). The change of second-order type is strategic, revolutionary, and often transformational. In nature, they are drastic, where the organization completely modifies its framework fundamentally (Nadler \& Tushman, 1990), aiming for a newer competitive edge (utt, 1995) and influencing the essential organizational capabilities (

Modern-day organizations adapt continuously (Correani, 2020) (Verhoef et al., 2019) (Weill \& Woerner, 2018). The turbulence in organizations often occurs due to competing and interdependent forces (Jacobides, 2018). Consequently, the organizations adapt and adopt various procedures and technologies (Kopalle, 2020). Organizations also adapt to grow and survive (McKinsey, 2020). Often, the changes occur in emergency or crisis situation (Hinings, 2018). A researcher (Huang, 2017) state that the organizational transformation may also happen due to double-loop learning.

The changes in the environment trigger changes in organizations of a fundamental nature (Boonstra, 2000). The issues involved in changes in these processes have implications related to turbulence and complexity in an organization or environment. Also, instability is caused due to changes in the environment, and management forces attempt to pull an organization back to balance with its environment through change and adaptation. Change processes involve problems, ambiguous and complex but known, that can be solved; an appropriate approach is organization development for problemsolving. Such change processes involve changes in structure, individual behavior, and culture which need people in the organization to seek out solutions for such common problems through an interactive learning process (French \& Bell, 1995).

Van de Van \& Poole (Van de Ven, 1995) presented a typology of organizational changes i.e., Teleological Model, Life Cycle Model, Dialectical Model, and Evolutionary Model. The teleological model assumes the occurrence of change as guided by a goal or a desired end state. Organizations have purposeful individuals who interact, develop common goals, and take actions to achieve them. The life cycle model is based on the metaphor of organic growth which explains changes leading from initiation till termination of an organization including start-ups, growth, maturity, and decline. Dialectical model state that organizations exist in a pluralistic setting where internal and external forces, factors, and events collide for control and domination, thereby, achieving stability and cause change. Lastly, the Evolutionary model is explained by the probabilistic and cumulative changes in organizational life on the pattern of variation, selection, retention, and survival of the fittest.

The research on organizational change has influenced multiple fields triggering interdisciplinary studies which employ specific theories, metatheoretical approaches, and methodologies (Leonardi, 2017)

Also, there are literary pieces that define goal-oriented, life cycle, dialectical and evolutionary forces in achieving change as found in works of Milton, Frost, Shelley, and Eliot and various other literary figures. On this similarity, the models will be termed as Miltonic, Frostian, Shelleyan and Eliotic models of change. 
To comprehend the processes involved in handling complex and extensive change, a novel unique research approach is required. Conventional academic research is insufficient to create knowledge about the multi-dimensional veracity of interactive learning. The present paper aims to merge the organizational concepts with the literary reflections in the pursuit of amalgamating discrete compartments of management sciences and the English language and literature. This would be an attempt to find close connections in the realms of organization management and English literature since both involve life, self-interpreting beings, activities, goals, and objectives. Both the fields encompass and are reflections of higher ideals of life, norms, society, and values. Many of the management concepts flow out of society and life which have found similar expressions in the English language and literature. Similarly, dynamic representations of life and activities in language and literature can impact organizational themes. Nevertheless, this analysis and research are guided by the pure values of objectivity combined with comparisons, reasoning, and analytical inquiry.

These explanations encompass many complexities that are clarified through applying specific dimensions which help to establish the typologies of change. The types and scope of change are the most employed variables found in the literature that can be related to designing change typologies. So, the changes can be illustrated along a continuum ranging from lowscope to high-scope or from evolutionary changes to strategic ones.

The study aims to bridge the gap in interdisciplinary research aiming to take benefit from the management sciences and literature for understanding and developing concepts. With this dimension of scope in focus, both extremes of continuum shall be analyzed according to the Van de Van typology and the poetic expressions found in the English language and literature. However, it should always be kept in mind that the actual changes are not an ideal pure sort but a mixture.

\title{
METHODOLOGY
}

Methodologically, the qualitative study employed content analysis. The content from English literature (being an international and understandable language across the globe) was purposively chosen which fulfilled the requirements of the objective and research question of the study. The themes and connections were built utilizing the grounded theory which was then compared and analyzed concerning the Van de Van' typology as stated in the literature review.

\section{ANALYSIS AND DISCUSSION}

\section{Miltonic Model of Change}

Milton is a seventeenth-century poet who through his famous Paradise Lost describes numerous tactics and procedures that carry significant implications for the organizational model of change. First, take a look at the poetic verses and then the connection with the management field can be established.

\section{“Paradise Lost"}

\author{
"What though the field is lost? \\ All is not lost; the unconquerable Will, \\ And a study of revenge, immortal hate, \\ And courage never to submit or yield: \\ And what is else not to be overcome?" (Milton 1667 as cited in (Hazlitt, 1960))
}

Milton's Paradise Lost, published in 1667, presented the satanic expressions that were goal-oriented and resolute. Like the Machiavellian prince, Satan was perceived to be an expert on dimensions of war and discipline, as demanded in such situations. Also, Satan could as be as precise as possible in the pursuit of his political goals with the utilization of strategies he deemed expedient. He though didn't take notice of charge of cruelty if that was meant to be keeping his subjects bound, united and faithful" (Vincent, 1952 as quoted in (Steadman, 1967)).

A model i.e., the teleological model of change in organizations is associated with Dewey (1933, as cited by Carnall, 1995). The organizations are taken as adaptive and purposeful. The leaders are instrumental in and agents of change as it is a necessity felt; for it is a process that is rational (Carnall, 1995). Thus, we can compare the presence of leaders, strategies to accomplish goals, the role of planning, and the effect of the teaming in the Miltonic mode of leadership and change and the Teleological mode.

For instance, the themes of his heroic struggle after losing the battle are hope "All is not lost", and endurance against difficulties and hopeless odds "And courage never to submit or yield" and the passion to overcome these are presented in the following poetic lines.

"That Glory never shall his wrath or might

Extort from me. To bow and sue for grace

With suppliant knee, and deify his power,

Who from the terror of this Arm so late 
Doubted his Empire, that were low indeed,

That were an ignominy and shame beneath

This downfall”. (Milton, 1667) as cited in (Hazlitt, 1960)

A commentator has lauded Satan's passion, virtue, bravery, faithfulness to his troops, and ambition (Blair, 1853). His ambition was so resolute that he thought even God's anger or force couldn't make him submit. He preferred punishment but would not surrender for mercy. Despair could not beat his strength which was as immense as his affliction. His muscle, vigor of body, power of action, and mind were incomparable and his designs vast. Firm, inflexible and determined was he, in the face of irreversible doom and loss of good (Hazlitt, 1960).

These are comparable to the subjective viewpoints, intentionality, and decisions in the teleological model that motivate change in the organization and assemble consensus for it among the subordinates. The leader's rationality, planning, incentives, assessments, rewards, engagement, strategy, and restructuring are the key features. The leader has a central position as he aligns expectations, goals, efforts, creativity, choices, and communications (Brill, 1997). Therefore, Satan vocalizes as the change agent communicates to the followers. The leaders in both paradigms are regarded to have the requisite skill and fortitude to plan, envision and enact in the face of challenges. Take some other poetic lines;

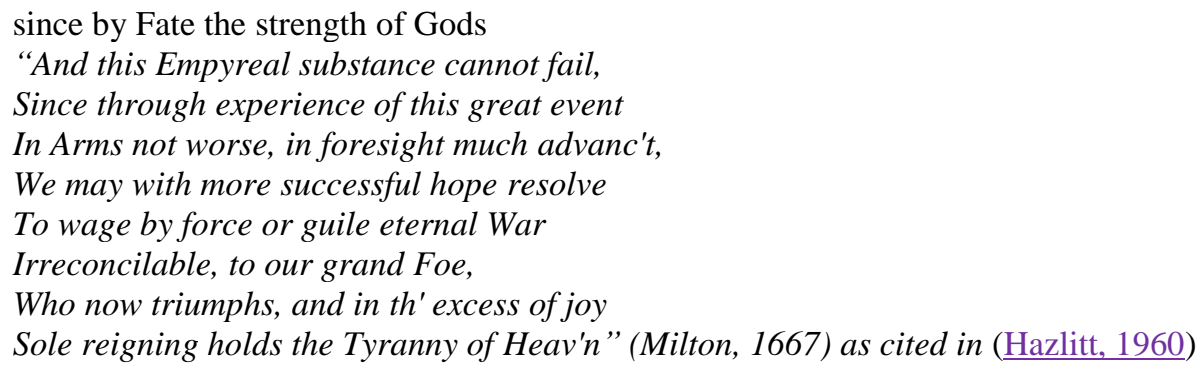

According to a scholar, Milton's Fiend is presented as a moral entity that is far greater than God. He persists in his "sublime" aim that he conceives to be brilliant despite torture, shame, defeat, and adversity. He is prepared for the most awful revenge upon his enemy for which he has crafted designs of exasperating him to inflict new torments (Shelley, 1944).

This is also found in the organizational change model. In the teleological model the goal planning, enforcing, and revising are based on experience. The leader's tools are collaboration, participation, and in-depth intervention towards engaging employees (Brill, 1997). The aims are high to attain new heights, structures, and principles.

Amid several inconsistencies and contradictions, Satan resolves to pursue a sophisticated, greater, and more persuasive strategy. He is not misled by false specious reasoning rather uses it to address the pressures. He experiences and analyses the need of the time and impending fear for his wellbeing along with the continuation of his mission. He, as a leader, avoids acting irrationally, blindly, and passionately as ordinary humans do. He constructively employs violent and intense passion to accomplish his goals (Coleman, 1998). A scholar illustrates Satan's leading role as "fortitude in adversity, enormous endurance, a certain splendid recklessness, remarkable powers of rising to an occasion, extraordinary qualities of leadership". And like a leader, he knows that motivating subordinates is vital to the task. "The whole aim of the speech is to instill a mood, to cheer spirits" (Waldock, 1947).

The same rational approach, need analysis, mission orientation, and action plans are very much representative of the teleological model. The leader here has to accumulate uniform approval for the goals to be successful in the face of a competitor which ironically is God in the case of Satan.

Also, Satan shrewdly stages his arrangement to wreck Adam and Eve by exhibiting the calculating and powerful reason indicative of an extraordinary human being. His decisions are firmly found in his soliloquy's end as he says 'farewell Hope' and persists to combat God. He presents ample evidence of resisting irrationality and utilizing sound acumen, despite his earlier beat. Satan's knack to infer from basic recognitions, truths about himself or God is exemplary (Coleman, 1998). The introductory speech in Hell is abundant in references where Satan lauds Beelzebub, which undoubtedly divulges his cooperation in the Satanic insurgence:

\author{
"If he whom mutual league, \\ United thoughts and counsels, equal hope, \\ And hazard in the Glorious Enterprise, \\ loin'd with me once". (Milton, 1667) as cited in (Hazlitt, 1960)
}

In the light of the above discussion, the Teleological Model by Van de Van (1995) can be analyzed which presents the case of a successful leader who creates a vision and culture for his team and followers in the organization just as Satan did in 
Milton's rhyme. The basic principles of this model are on the satanic footings; the leader develops goals, vision, and mission; leadership is supportive and creative; subordinates are trained and motivated; decisions are actively taken based on facts; planning and collaboration are deemed significant (Freed, 1997). Regular need identification and problem-solving are prerequisites for change. The behavior is goal-oriented by pronouncing norms and overcoming resistance (Carr, 1996). The leader here has similarities to Satan; therefore, the Teleological Model of Van de Van (1995) is an extension of the Miltonic Model of leadership and change. So, it is referred to here as the Miltonic Model of Organizational Change. Both work in anticipation of the impending challenges to sail the ship through difficulties towards the success and destination. This reflection of the poetic model of organizational change found in literature helps the organization to understand the language of Management by objectives (MBO) and to steer and control leader's qualities in favor of increasing productivity and performance - thus, has managerial psychology perspective.

Let's take another model of change now.

\section{Frostian Model of Change}

Another model of change can be extracted from the early twentieth-century poet. The comparison of Frost's poem and the dialectical model of change shall go side by side.

\section{"The road not taken"}

In the renowned poem called "the road not taken," Robert Frost develops a model of life in the poem. There are paths in the woods and folks traveling on roads which are ancient and profound metaphors for life pattern, its conflicting ideas, crises, and crucial decisions. These concepts are respectively observed in organizational life as well. For instance,

\section{"Two roads diverged in a yellow wood And sorry I could not travel both" (Frost, 1915)}

There is a reference of two roads which are like two opposing values. Both the roads can't be trodden on at the same moment as the two conflicting values can't be followed at one time.

This life and literary concept presented in 1915 has deep meanings for organizational models of change. Juxtaposing it with Greiner's (1972) dialectical model, it can be analyzed that the basic assumptions are similar. As (Kezar, 2001) stated, that the term dialectical has roots in the Hegelian-Marxian perspective, it indicates a value, pattern, norm, or ideal has an everexistent polar opposite in an organization and only one of the two conflicting forces shall prevail. Also, in particular; life, organizational change, and dialectical model symbolize the nexus of free will and determinism.

\section{"And be one traveler, long I stood \\ And looked down one as far as I could \\ To where it bent in the undergrowth" (Frost, 1915)}

There seems to be a conflict to choose between the two paths that are separate and never meet and there is individual confusion as opposed to communal support and the ensuing period of helplessness and lack of progress. This life conflict is similar to the dialectical conflict where there are coalitions, periods of inactivity, sudden turn of events like choosing the path, and the continued struggle, tussle, and confusion between two opposing forces.

According to a study (Baldridge, 1977), the dialectical model does not assume the involvement of everyone, instead, it highlights the period of prevailing inactivity. A scholar (Kezar, 2001) explains that communalism has an opponent in the existence of individualism. The two rival forces always contradict each other and with time, the change is realized through the interaction of these rival forces.

"Then took the other, as just as fair

And having perhaps the better claim,

Because it was grassy and wanted wear;

Though as for that, the passing there

Had worn them really about the same". (Frost, 1915)

Now, the selection of a path, which option can be a 'better claim', is a result of conflict resolution, convincing, and illumination. This phenomenon resembles the clash of belief systems culminating in radical change. Similarly, (Bolman, 1991) describes the conflict as an innate characteristic of human interaction. The conclusion of this kind of change is an improvised organizational identity and ideology. To conclude, there are streaks of consciousness-raising, bargaining, persuasion, and social movement.

"And both that morning equally lay

In leaves, no step had trodden black. 
Oh, I kept the first for another day!

Yet knowing how way leads on to way,

I doubted if I should ever come back" (Frost, 1915)

As in life, one does not know beforehand of consequences of the choice and its outcomes. The course is established by the accrual of choice and chance and the two can't be separated. The poem appears to be preoccupied with the ambiguity of how the actual present will appear from a prospective point in time. The poem is instilled with the expectation of profound remorse. The title is ironic; "The Road Not Taken" and not "The Road Less Traveled". The same is the case in the dialectic model, where the outcome of thesis (A) and antithesis (Not A) is synthesis (Not - Not A).

Looking deeply, the poem has resonance with the dialectical model. Kazer (2001) believes that rationality and progress are not essentially a part of the dialectical model of change. This type of conflict may not surely result in a better organization like the uncertainty of an apparent "better claim" in the poem.
"I shall be telling this with a sigh
Somewhere ages and ages hence:
Two roads diverged in a wood and I --
I took the one less travelled by,
And that has made all the difference" (Frost, 1915)

Even as the poet makes a choice, he is aware that he may speculate at what was irrevocably lost. The impossible or the indecipherable other road has been abandoned. Also, there is the dilemma of no Right Path; it is just the chosen path or the other path.

The researcher (Kezar, 2001) has a similar view that Van De Van's dialectical model (1995) is the departure from rationality and linearity. The same is explained in Frost's No Right Path (1915). Morgan's (1986) model of erratic and regressive change explains such remorse. Thus, it can be concluded that the thesis can be different from anti-thesis which also is distinct from the synthesis which is a commonality in Van de Van's Dialectical Model and Frostian concept. And, hence, it is termed here as the Frostian Model of Organizational Change. There is not a single right choice; all depends upon which of the two rival forces dominate and takes over the other. This reflection of the poetic model of organizational change in literature helps an organization to understand the language and psychology of dialectical model and mechanistic organizations (which can be change-resistant leading to poor performance) in favor of managerial perspective - which is increasing productivity and performance by converting it into a learning organization.

\section{Shelleyan Model of Change}

The early nineteenth-century poet brought forth a concept in his poem Mutability that has solemn repercussions for the life cycle model. Let's analyze the poem to find similarities with the organizational change model.

"Mutability"
"We are as clouds that veil the midnight moon;
How restlessly they speed and gleam and quiver,
Streaking the darkness radiantly! yet soon
Night closes round, and they are lost forever.
Or like forgotten lyres whose dissonant strings
Give various response to each varying blast,
To whose frail frame no second motion brings
One mood or modulation like the last". (Shelley, 1944)

Shelley, through this 1816 era's poem, here compares human beings to clouds appearing in the night which gleam radiantly in the night, shimmer in the dark sky and upon the gloomy earth but soon they vanish as the sun rises. There is another simile comparing man to the different melodies played by lyres due to the variation of each experience every time. Thus, the meaning emerging from these lines is the mutability of human life and its transient nature. The only permanent thing in the universe is the change itself. Also, the pattern is predetermined with sequential phases in the appearing, glowing, and diminishing in the first case and constant change in the second as the experiences vary every time.

According to a critic (Clark, 1954): "Just as life transmutes other elements to itself, so living bodies must constantly shed parts of themselves to continue to live. In 'Shelley's A Refutation of Deism,' Eusebes (1816, as cited in Clark, 1954) expresses a further consequence of this world in which nothing perishes but everything changes: 'no organized being can exist without a constant separation of that substance which is incessantly exhausted, nor can this separation take place otherwise than by the invariable laws which result from the relations of matter." 
Examining the life cycle model, presented by a scholar (Haire, 1959) that originated from the child development studies, we find that it concentrates on the different phases of organizational growth, development, maturity, and decline; all imbued with change (Levy \& Merry, 1986). This is the natural pattern of life too.

This life cycle model has grave connections with Shelley's romantically fashioned pattern of a natural phenomenon that places the humans in the physical realm same as nature and then centres on the human agency by relating them to things invented "like forgotten lyres." So, in a similar vein, organizations in the social realm can be compared to human life.

Shelley found a life cycle pattern in the natural world and the life cycle model found a life cycle flow in the organizational world. Shelley's poem focus on the eternal change in the human condition and its mutability, a natural condition, in the life of the clouds that roam here and there and then "lost forever" and then "strings give a various response to various blasts.....modulation sounds like the last." The theme is change and nothing is constant. Similarly, the life cycle model highlights constant mutation in the organizations from the start-up to the decline. A researcher (Goodman, 1982) calls it stages of birth, development, maturity, revitalization, and decline. The case is exquisitely presented by researchers (Miller, 1980) that the occurrence of change is not due to the necessity or wish felt by people rather as a natural progression that is unstoppable and unalterable.

"We rest—a dream has power to poison sleep;
We rise-one wandering thought pollutes the day;
We feel, conceive or reason, laugh or weep,
Embrace fond woe, or cast our cares away:-
It is the same!-For, be it joy or sorrow,
The path of its departure still is free;
Man's yesterday may ne'er be like his morrow;
Nought may endure but Mutability" (Shelley, 1944)

Shelley introduces human thought and emotions which are forever changing. Nevertheless, there may not be any control over the constant mutability of mind, or in some instances, one can make one's own change.

This has consonance with the change in organizations and employees. Change happens in the organization as individuals change and adapt according to its life cycle. The model is deterministic in organizational change and stages of development (Rajagopalan \& Spreitzer, 1997).

The change in thoughts is an internal process and organizational change circulates internal practices and processes as compared to external aspects. The same is assumed by the life cycle model that change would not happen smoothly without the people's readiness thereby implying certain steps of activities. Renewal and expansion are a process involving managers responding to environmental demands.

Lastly, Shelley called thoughts and the emotions "free," suggesting that regardless of sorrows, a brighter future eventually emerges. A researcher (Bolman, 1991) explains that though the environment is uncertain and threatening, betterment can be achieved through training and development, communication, and growth.

These sorrows are seen in the ambiguity and threats of the environment. The thoughts are free and one is free to train, develop, communicate and grow. The outcome is the new morrow like the development of a new organizational identity. (Van de Ven, 1995) concludes that the result of these processes is the new organizational identity.

In the light of the above discussion, it can be concluded that Shelley considers the human condition as one of narcissism and vanity. The themes of 'once out of sight then it is out of mind' in clouds that are "lost forever" and the lyre which is "forgotten." The idea is that like the clouds and the instruments, human beings are easily forgotten as they impede making change or significance in the world, also, they decline, die, and vanish into the night. Similarly, Van de Van's (1995) life cycle model emphasizes that the greater efficiency, profitability, momentum, energy of the organization, and training is similar to adulthood. As human beings get engrossed in the environment and traditions, an organization's productivity is reduced. Like human decline, organizations lose performance and success too. Just like humans die, the organizations stop functioning too and eventually vanish like clouds. Therefore, the life cycle model has roots in Shelleyan thought and thus, termed here as Shelleyan Model of Organizational Change. This reflection of the organizational and poetic model of change indicated in literary language helps organizations to become organic organizations that mould themselves with the environment to favor productivity and performance i.e., a psychological and managerial perspective.

\section{Eliotic Model of Change}

Burnt Norton by T.S. Eliot, a late nineteenth and early twentieth-century poet, throws light on the continuation and evolution of time into one form or the other having continuity in diversity yet seems a gradual connected process. This is but another model of an evolutionary model of organizational change. 


\title{
“Burnt Norton"
}

\author{
"Time present and time past \\ Are both perhaps present in time future, \\ And time future contained in time past. \\ If all time is eternally present \\ All-time is unredeemable”. (Eliot, 1936 as cited in (Hazlitt, 1960))
}

The Quartets of Eliot, when taken together, embody a learning journey from the profound ignorance of time towards an illuminating and awakening state in eternity. As Burnt Norton's introductory lines operate to bridge the road atlas to describe that journey. This passage is evidence of how soundly Eliot comprehends time. He sandwiches past, present, and the future to create the ceaseless moment and the natural quality and condition of time same found in physics.

Like Eliot's learning journey from ignorance to illumination, the evolutionary model proceeds from an uncertain struggle for survival to the selection of the fittest where things have fully evolved and in illumination. Eliot understands time whose inherent quality is that it evolves and takes forms. Similarly, the evolutionary model gradually accumulates changes of the past, present, and future to develop a mature and grown state of things. The Evolutionary model was presented in 1977 by Hannan \& Freeman, but one is forced to find the model in Burnt Norton published in 1935.

Morgan (1986) presents the evolution of systems and organizations naturally evolving. However, evolution is fundamentally deterministic upon which people have little influence on the character and the course of the change progression (Hrebiniak, 1985). The model highlights the impossibility of organizational units to map or respond in an anticipating manner and all they can do is to manage new challenges. The focus is not on discrete activity or event but a slow process unfolding realities (Kieser, 1989). Change and adaptation is the need of the organizations to survive due to the demands of changing environments (Cameron, 1986). Changes are accumulated in the self-organizing organizations as in self-producing organisms. The systems approach reflects that the organizations have interrelated and interdependent structures. One unit has implications for the other parts of the system. The nature of the system is founded on interactivity and the connectedness of activities where change is not isolated but all prevailing. The systems are in open relation with the nature and environment and changing as per the contextual demands (ㅁorn, 1999) (Morgan, 1986).

Morgan's (1986) view of organizations has an evolving pattern which is a deterministic, time-dependent, uncertain, and future-oriented phenomenon. One can locate the impossibility of organizations to plan or respond as we see the unpredictability and ambiguity of the future as it yet has to unfold. The slow process of unfolding realities is found in organizations and in time too. Change and adaptation is the need of the organizations to survive and the past is also never the same as present or future. Changes are accumulated in the organizations as in time which comprises of past, present, and future. Like the systems approach's interrelatedness, the past, present, and future are interdependent. As system units have implications for each other, past, present and future do have certain ramifications for each other. The system's interactivity and connectedness, where change is not isolated but prevalent, is explained in time where past, present, and future are interlinked, not isolated but time is all prevailing. The timelike systems are open to nature and the environment and changes as it passes on according to the contextual demands (․ Sporn, 1999) (Morgan, 1986).

"The end precedes the beginning,

And the end and the beginning were always there

Before the beginning and after the end.

And all is always now". (Eliot, 1936 as cited in (Hazlitt, 1960))

Eliot emphasizes that the past contains the future which is a truism when time is perceived as a sequential flow of the time gone has the seeds of the future by first flowing into the present and then into the future and also the future reflects present which runs into the past. The past and the present ought to be found in the future since what is past and currently the present have to precede the future. Moreover, Eliot qualifies the thesis that they have to be found since the future, contrasting the past and the present, has yet to be shaped and continues to be forever uncertain.

Eliot's thesis about the past contains the future explained above is evident in organizations that have seeds of the past, present, and future to some extent as visible in its growth and shape but they continue to be forever uncertain in their developments.

Morgan (1986) calls to change a slow course or process of mutations progressively formed by environmental impacts. Development of organizations is like future time i.e., unplanned and uncertain but more adaptive and selective. The culture and structure of organizations are continuous, having an element of the past, the potential for the present, and uncertainty of the future. Prigogine states that the organizations become coherent and mature but at the same time unstable. Organizations depend on resources, organizations, and the environment, and change ensues through this interactive evolutionary model 
(Sporn, 1999). Cameron (1986) suggests that managers choose their environment, scan it and predict it to steer through the course of progression in organizational life. The model is somewhat deterministic. The decisions and actions of groups and organizations shape their success and survival.

In the light of the above, it is analyzed that the Time patterns of Eliot are like Morgan's change which is a slow process with mutations. Like Prigogine's assumptions, coherent organizations' time is also coherent but at the same time unstable. As organizations depend on organizations and environment and are interactive so does current time depends on what has gone and what is coming up to be meaningful. Cameron's course of progression in organizational life is similar to the time's progression, diversification, and manipulation where the actions of the past have an impact on the future. Therefore, Van de Van's (1995) Evolutionary Model and Eliot's progression of phenomena have similar time factor which helps change to take place with time and lead to growth and decline. In this context, the Eliotic Model of Organizational Change represents the explanations offered by the Evolutionary model. This reflection of the poetic model of organizational change as expressed in the language of literature takes organizations as whole systems which interact with the environment to favor productivity and performance - which is very much a managerial perspective.

\section{CONCLUSION}

This article thus has struggled to established synchroneity between the field of organizational change and English language and literature based on logic found in the processes of nature and human life. This article, through reasoning and analysis, has developed four life-processes based models i.e., Miltonic, Frostian, Shelleyan and Eliotic models of organizational change which seem to be preceding teleological, life cycle, evolutionary and dialectical models of organizational change. The realm of literature and language reflects human and social life which has implications for business, management, organizational life and psychology. Thus, various fields can facilitate development and explain management concepts that would be much aligned and in consonance with each other to promote harmony in life, activities, and the world.

\section{LIMITATION AND STUDY FORWARD}

The study is limited to the well renowned poetic expressions and thus, other poetic expressions can be analysed to develop or assess new or existing models of change. The study presents new horizons for future research where the literature can be analysed to extend the organizational models of change including nature, antecedents, sources, levels, and outcomes of such change models. However, the responses towards change and adaptive performance (Jansen et al., 2016) and the dimensions of attitudes towards change in organizations calls for more future research (Oreg et al., 2016).

\section{ACKNOWLEDGEMENT}

I acknowledge my parents for their continued moral support for my research studies. Personal resources have been employed and no financial support was sought from any other quarter.

\section{REFERENCES}

1. Bakker, A. B. (2018). Job crafting among health care professionals: The role of work engagement. Journal of Nursing Management, 26, 321-331. https://doi.org/10.1111/jonm.12551

2. Baldridge, J. C. (1977). Alternative models of governance in higher education. (Baldridge, G. L. Ed.) Governing academic organizations, 2-25.

3. Blair, H. (1853). Lectures on Rhetoric and Belles Letters. (Dale., T. Ed.). Dublin: printed for Messrs. Whitestone, Colles, Burnet, Moncrieffe, Gilbert

4. Bolman, L. \&. (1991). Leadership and management effectiveness: A multi-frame, multi-sector analysis. Human Resource Management. 30(4), 509-534. https://doi.org/10.1002/hrm.3930300406

5. Boonstra, J. (2000). Lopen over water: Over dynamiek van organiseren, vernieuwen en leren (Walking on water: About dynamics of organizing, renewing and learning). Amsterdam: Vossiuspers AUP. https://doi.org/10.5 $117 / 9789056291259$

6. Brill, P. \& Worth, R. (1997). The four levers of corporate change. New York: AMACOM.

7. Cameron, K. S. (1986). Effectiveness as a paradox: Consensus and conflict in conceptions of organizational effectiveness. Management Science, 32(5), 539-553. https://doi.org/10.1287/mnsc.32.5.539

8. Carnall, C. (1995). Managing Change in Organizations (2nd. Ed.) London: Prentice-Hall.

9. Carr, D. \& Hard, K. (1996). Managing the change process: A field book for change agents, consultants, team leaders, and reengineering managers. McGraw-Hill Education.

10. Clark, D. L. (1954). ed., Shelley's Prose: or the Trumpet of a Prophecy. University of New Mexico Press.

11. Coleman, H. (1998). Man in Devil's Guise: Satan's Exceptional Hunlanity in Milton's Paradise Lost. Christchurch, Canterbury, New Zealand: University of Canterbury.

12. Correani, A. D. (2020). Implementing a digital strategy: Learning from the experience of three digital transformation projects. California Management Review, 62(4), 37-56. https://doi.org/10.1177/0008125620934864 
13. Cortet, M. R. (2016). PSD2: The digital transformation accelerator for banks'. Journal of Payments Strategy \& Systems. 10, 13-27.

14. Dery, K. S. (2017). The digital workplace is key to digital innovation'. MIS Quarterly Executive. 16, 135-152.

15. Freed, J. K. (1997). A Culture for Academic Excellence. Washington, DC: George Washington University Press.

16. French, W. \& Bell, C. (1995). Organization development: Behavioral science interventions for organization improvement (5th ed). Prentice-Hall.

17. Frost, R. (1915). Collected Poems, Prose, and Plays. New York: The Library of America.

18. Gage, John T. (1982). Rhetoric and Dialectic in Robert Frost"s "A Masque of Reason", Pacific Coast Philology. 17 (1/2), 82-91. https://doi.org/10.2307/1316397

19. Goodman, D. (1982). Optimal life histories, optimal notation, and the value of reproductive value. American Naturalist. 119(6), 803-823. https://doi.org/10.1086/283956

20. Greiner, L. (1972). Evolution and revolution as organizations grow", Harvard Business Review, (July/Aug.). 37-46.

21. Haire, M. (1959). Modern Organization Theory. John Wiley.

22. Hazlitt, W. (1960). On Shakespeare and Milton, Lectures on the English Poets. Project Guttenburg.

23. Hinings, B. G. (2018). Digital innovation and transformation: An institutional perspective. Information and Organization. 28, 52-61. https://doi.org/10.1016/j.infoandorg.2018.02.004

24. Hrebiniak, L. W. (1985). Organizational adaptation: Strategic choice and environmental determinism. Administration Science Quarterly, 30(3), 336-349. https://doi.org/10.2307/2392666

25. Huang, J. H. (2017 ). Growing on steroids: Rapidly scaling the user base of digital ventures through digital innovation. MIS Quarterly, 41, 301-14. https://doi.org/10.25300/MISQ/2017/41.1.16

26. Hutt, M. W. (1995). Hurdle the Cross-Functional Barriers to Strategic Change, Sloan Management Review. 36 (3), 22-30.

27. Jacobides, M. C. (2018). Towards a theory of ecosystems. Strategic Management Journal,(39), 2255-76. https://doi.org/10.1002/smj.2904

28. Jansen, K. J., Shipp A. J. \& Michael J. H. (2016). Champions, converts, doubters and defectors: The impact of shifting perceptions on momentum for change. Personnel Psychology, 69, 673-707. https://doi.org/10.111 $1 /$ peps. 12120

29. Kezar, A. (2001). Understanding and Facilitating Organizational Change in the 21st Century: Recent Research and Conceptualizations. ASHE-ERIC Higher Education Report, 28(4). Jossey-Bass Higher and Adult Education Series.

30. Kieser, A. (1989 ). Organizational, Institutional, and Societal Evolution: Medieval Craft Guilds and the Genesis of Formal Organizations. Administrative Science Quarterly, 34 (4), 540-64. https://doi.org/10.2307/2393566

31. Kopalle, P. K. (2020). How legacy firms can embrace the digital ecosystem via digital customer orientation. Journal of the Academy of Marketing Science, 48, 114-31. https://doi.org/10.1007/s11747-019-00694-2

32. Kotera, Y. C.-V. (2020). Psychological impacts of the New Ways of Working (NWW): A systematic review. . International Journal of Environmental Research and Public Health, 17. https://doi.org/10.3390/ijerph17145080

33. Kotter, J.P. (1995). Leading change: why transformation efforts fail. Harvard Business Review. 73 (2):59-67.

34. Leonardi, P.M. (2017). Out of the Poole and into the Ocean: Understanding Processes of Organizational Change Through the Work of Marshall Scott Poole. In: Szabla D., Pasmore W., Barnes M., Gipson A. (eds) The Palgrave Handbook of Organizational Change Thinkers. Palgrave Macmillan, Cham. https://doi.org/10.1007/978-3-319-49820-1_88-1

35. Leonardi, P. M. (2017). How to build high impact theories of organizational communication: Strategies of discovery and reconceptualization. Management Communication Quarterly, 31(1), 123-129. https://doi.org/10.11 $77 / 0893318916675426$

36. Levy, A. \& Merry, U. (1986). Organizational transformation: Approaches, strategies, theories. Greenwood Publishing Group.

37. McKinsey (2020). The Digital-Led Recovery from COVID-19: Five Questions for CEOs. https://www.mckinsey.com/business-functions/mckinsey-digital/our-insights/the-digital-led-recovery-from-covid-1 9-five-questions-for-ceos\#

38. Miller D, F. P. (1980). Momentum and revolution in organizational adaptation. Academy of Management Journal, 23(4), 591-614. https://doi.org/10.5465/255551

39. Morgan, G. (1986). Images of organization. Beverly Hills CA: Sage.

40. Nadler, D. A., \& Tushman, M. L. (1990). Beyond the Charismatic Leader: Leadership and Organizational Change. California Management Review, 32(2), 77-97. https://doi.org/10.2307/41166606

41. Oreg, S., Bartunek, J, M., Lee, G. \& Do B, (2016 ). An affect-based model of recipients' responses to organizational change events. Academy of Management Review, 43(1), 65-86. https://doi.org/10.546 $\underline{\text { 5/amr.2014.0335 }}$ 
42. Pilny, A., Schecter, A., Poole M., Contractor, N. (2016). An illustration of the relational event model to analyze group interaction processes. Group Dynamics: Theory, Research, and Practice. 20(3), 181-195. https://doi.org/10. 1037/gdn0000042

43. Rajagopalan, N., \& Spreitzer, G. (1997). Toward a Theory of Strategic Change: A Multi-lens Perspective and Integrative Framework. The Academy of Management Review, 22(1), 48-79. https://doi.org/10.2307/259224

44. Ruiz, J. L. (1999). Cambio estratégico y renovación organizativa: utilización de las capacidades latentes y periféricas (Strategic change and organizational renewal: use of latent and peripheral capabilities). Revista Europea de Dirección y Economía de la Empresa, 8 (4), 71-82.

45. Schalk, R., Campbell, W.J., \& Freese, C. (1998). Change and employee behavior. Leadership \& Organization Development Journal, 19(3), 157-163. https://doi.org/10.1108/01437739810210202

46. Schaufeli, W. B. (2015). Engaging leadership in the job demands-resources model. Career Development International. 20, 446-463. https://doi.org/10.1108/CDI-02-2015-0025

47. Shelley, P. (1944). A Defence of Poetry. Modern Language Quarterly.

48. Sporn, B. (1999). Adaptive University Structures: an analysis of adaptation to socioeconomic environments of US and European universities. Jessica Kingsley Publishers.

49. Steadman, J. (1967). The Idea of Satan as the Hero of "Paradise Lost". Proceedings of the American Philosophical Society. Symposium on John Milton (Aug. 13, 1976), 120(4), 253-294.

50. Van de Ven, A., \& Poole, M. (1995). Explaining Development and Change in Organizations. The Academy of Management Review, 20(3), 510-540. https://doi.org/10.2307/258786

51. Verhoef, P. C., Broekhuizen, T., Bart, Y., Bhattacharya, A., Dong, J. Q., Fabian, N., \& Haenlein, M. (2021). Digital Transformation: A Multidisciplinary Reflection and Research Agenda. Journal of Business Research, 122, 889901. https://doi.org/10.1016/j.jbusres.2019.09.022

52. Waldock, A. J. (1947). Paradise Lost and its Critics. Cambridge: Cambridge University Press.

53. Weill, P. \& Woerner, S. L. (2018 ). Is your company ready for a digital future? MIT Sloan Management Review, 2125. 